\title{
Volume-sensitive chloride channels are involved in cisplatin treatment of osteosarcoma
}

\author{
SIYI CAI ${ }^{*}$, TAO ZHANG ${ }^{2 *}$, DANDAN ZHANG ${ }^{3},{\text { GUIXING } \text { QIU }^{1} \text { and YONG LIU }}^{1}$ \\ ${ }^{1}$ Department of Orthopedics, Peking Union Medical College Hospital, Chinese Academy of Medical Sciences \\ and Peking Union Medical College, Beijing 100032; ${ }^{2}$ Department of Internal Medicine, First Affiliated Hospital of \\ Jinan University, Guangzhou, Guangdong 510630; ${ }^{3}$ Department of Histology and Embryology, \\ Medical College of Jinan University; Guangzhou, Guangdong 510632, P.R. China
}

Received February 28, 2014; Accepted November 14, 2014

DOI: $10.3892 / \mathrm{mmr} .2014 .3068$

\begin{abstract}
Chemotherapy is the most common therapeutic strategy used to treat osteosarcoma. The present study aimed to investigate the effects of functionally activated chloride channels on cisplatin-induced apoptosis of MG-63 human osteosarcoma cells. An MTT assay and flow cytometry were used to detect proliferation and apoptosis of the cells, respectively. Live cell imaging was used to detect volume changes in response to treatment with cisplatin and/or chloride channel blockers. The effects of these treatments on chloride currents were also assayed using the patch-clamp technique. The results of the present study indicate that chloride channel blockers may suppress cisplatin-induced apoptosis. The MG-63 cells cultured with cisplatin demonstrated an apoptotic volume decrease, as well as suppression of cell proliferation; which were reversed by co-treatment with chloride channel blockers. These results suggest that cisplatin may activate chloride channels, and that channel activation is an early signal in the pathways that lead to cisplatin-induced apoptosis and inhibition of proliferation in MG-63 cells. In conclusion, these results indicate that chloride channels have an important role in cisplatin treatment of osteosarcoma.
\end{abstract}

\section{Introduction}

Osteosarcoma is the most common primary malignant bone tumor. A critical issue in the clinical therapy of osteosarcoma is the development of treatment strategies that kill cancer

Correspondence to: Professor Yong Liu, Department of Orthopedics, Peking Union Medical College Hospital, Chinese Academy of Medical Sciences and Peking Union Medical College, 1 Shuaifuyuan, Dongcheng, Beijing 100032, P.R. China

E-mail: liuyongxh@163.com

${ }^{*}$ Contributed equally

Key words: cisplatin, chloride channel, osteosarcoma cells without harming normal healthy cells. (1). Cisplatin (cis-diamminedichloroplatinum II) is one of the most effective and widely used chemotherapeutic agents to treat solid tumors (2). Cisplatin causes DNA damage, which may lead to cell apoptosis; however, cisplatin treatment is often ineffective due to acquired drug resistance (3). Ion channels contribute to massive ion fluxes across plasma membranes and have important roles in diverse cell processes in healthy and disease states, including excitability, contraction, cell cycle regulation and metabolism, (4). Previous studies have suggested that chloride channels are associated with cell volume regulation, proliferation, cell cycle control and migration, as well as apoptosis (5-7). Apoptotic volume decrease (AVD) usually indicates cell apoptosis and is activated by ionic efflux, particularly of chloride ions, through volume regulatory anion channels (8). Ion channels have previously been proposed as potential targets for cancer therapy. A previous study suggested that treatment with a specific inhibitor of the cystic fibrosis transmembrane conductance regulator may be a novel therapeutic approach in the prevention of cisplatin-induced nephrotoxicity, without affecting the antitumor efficacy of cisplatin (9). Furthermore, impaired activity of volume-sensitive, outwardly rectifying (VSOR) chloride channels has been shown to contribute to the acquisition of cisplatin resistance in A549/CDDP cells (10). Conversely, Su et al (11) demonstrated that suppression of chloride channel 3 resulted in the inhibition of Akt and autophagy, which may enhance the therapeutic benefit of cisplatin in U251 human glioma cells. The present study aimed to investigate the role of chloride channels in cisplatin-induced apoptosis of MG-63 cells.

\section{Materials and methods}

Materials. All of the chemicals used in the present study were purchased from Sigma-Aldrich (St. Louis, MO, USA). The isotonic bath solution contained (in $\mathrm{mM}$ ): $70 \mathrm{NaCl}, 0.5 \mathrm{MgCl}_{2}$, $2 \mathrm{CaCl}_{2}, 10 \mathrm{HEPES}$ and $140 \mathrm{D}$-mannitol. The isosmotic solution was produced by replacing $70 \mathrm{mM} \mathrm{NaCl}$ with equimolar $\mathrm{NaI}, \mathrm{NaBr}$ or sodium gluconate. The pipette solution consisted of (in mM): $70 \mathrm{~N}$-methyl-D-glucamine chloride, $1.2 \mathrm{MgCl}_{2}$, 10 HEPES, 1 EGTA, 140 D-mannitol and 2 ATP. Osmolarity 
of the solutions was detected using an automatic cryoscopic osmometer (Osmomat 030; Gonotec, Berlin, Germany). The $\mathrm{pH}$ of all bath and pipette solutions was adjusted to 7.4 and 7.25, respectively. The chloride channel blocker, 5-nitro-2-(3-phenylpropylamino)-benzoate (NPPB; $100 \mu \mathrm{mol} / \mathrm{l}$; Sigma-Aldrich), was dissolved in dimethyl sulfoxide (DMSO; $100 \mathrm{mM}$; Sigma-Aldrich), and the other chloride channel blocker tamoxifen (20 $\mu \mathrm{mol} / \mathrm{l}$; Sigma-Aldrich) was dissolved in methanol anhydrous. NPPB and tamoxifen were diluted to final concentrations using isotonic solutions.

Cell culture. The MG-63 human osteosarcoma cells (American Type Culture Collection, Manassas, VA, USA; no. CRL-1427) were cultured in Dulbecco's modified Eagle's medium (DMEM; Gibco Life Technologies, Carlsbad, CA, USA) supplemented with $10 \%$ fetal calf serum (FCS), $100 \mathrm{IU} / \mathrm{ml}$ penicillin and $100 \mu \mathrm{g} / \mathrm{ml}$ streptomycin (Sigma-Aldrich) in a humidified chamber containing $5 \% \mathrm{CO}_{2}$ and $95 \% \mathrm{O}_{2}$, at $37^{\circ} \mathrm{C}$. The cells were collected at the logarithmic growth phase, resuspended, plated on coverslips and incubated for $1 \mathrm{~h}$ prior to further analysis.

Chloride current recordings. Following stabilization of the background chloride current in isotonic solution, the bath solution was changed to isotonic solution containing $2 \mu \mathrm{g} / \mathrm{ml}$ cisplatin (CDDP) for 30-50 min. Once the cisplatin activated currents had reached their maximum, the bath solution was changed to cisplatin solution containing $100 \mu \mathrm{mol} / 1 \mathrm{NPPB}$ or $20 \mu \mathrm{mol} / 1$ tamoxifen for $\sim 30 \mathrm{~min}$. Whole-cell $\mathrm{Cl}^{-}$currents were recorded using the patch-clamp technique with 5-10 M $\Omega$ pipette resistance and an EPC-9 patch clamp amplifier (HEKA Electronik, Lambrecht/Pfalz, Germany). Whole-cell currents of individual cells were maintained at a constant voltage, then amplified and filtered at $2.9 \mathrm{kHz}$. The $\mathrm{Cl}^{-}$equilibrium potential was set to $0 \mathrm{mV}$, then stepped to \pm 40 and $\pm 80 \mathrm{mV}$ for $200 \mathrm{~ms}$ repeatedly (12), with a $4 \mathrm{sec}$ interval between pulses in voltage clamp mode, at $20-24^{\circ} \mathrm{C}$. The currents were measured $10 \mathrm{msec}$ after the onset of voltage steps. The background current was normalized in isotonic solution. The percentage of inhibition of the chloride channel blockers was calculated using the following equation: Inhibition $(\%)=\left[\left(\mathrm{C}_{\mathrm{CDDP}}-\mathrm{C}_{\mathrm{Iso}}\right)-\left(\mathrm{C}_{\mathrm{Blocker}}-\mathrm{C}_{\mathrm{ISO}}\right)\right] /\left(\mathrm{C}_{\mathrm{CDDP}}-\mathrm{C}_{\mathrm{Iso}}\right) \times 100$, where $\mathrm{C}_{\mathrm{Iso}}$ is the background current under isotonic conditions; $\mathrm{C}_{\mathrm{CDDP}}$ is the maximal stable current following exposure to cisplatin; and $\mathrm{C}_{\mathrm{Blocker}}$ is the current recorded following treatment with the chloride channel inhibitors.

Measurements of cell volume. Cells in the control group were incubated under isotonic conditions for $360 \mathrm{~min}$. Cells in the treatment groups were incubated under isotonic conditions for $10 \mathrm{mins}$, then administered $2 \mu \mathrm{g} / \mathrm{ml}$ cisplatin alone or in combination with $20 \mu \mathrm{mol} / 1$ tamoxifen, and then incubated under isotonic conditions for a further 350 mins. Cells in the same field of view were imaged using an inverted phase contrast microscope (DMI6000 B; Leica Microsystems GmbH, Wetzlar, Germany) at $20-24^{\circ} \mathrm{C}$, then analyzed using Scion software (Scion Corporation, Torrance, CA, USA) at the following time points: $0,5,10,15,20,30,40,60,80,100,140,180,220,260,300$ and $360 \mathrm{~min}$. The cell volume (V) was calculated from measured cell diameters (d) using the following equation: $V=4 / 3 \pi(d / 2)^{3}$.
Proliferation and apoptosis analysis. An MTT assay was used to detect the rate of cell proliferation. Cells were cultured in control medium (DMEM supplemented with FCS and antibiotics) or medium containing cisplatin $(2 \mu \mathrm{g} / \mathrm{ml})$ alone or in combination with $100 \mu \mathrm{mol} / \mathrm{l} \mathrm{NPPB}$ or $20 \mu \mathrm{mol} / 1$ tamoxifen for $72 \mathrm{~h}$. Cell suspensions containing $2.5 \times 10^{7}$ cells $/ 1$ were plated in 96 -well culture plates, at a volume of $100 \mu \mathrm{l}$ per well. The cells were incubated in normal media or media containing $2 \mu \mathrm{g} / \mathrm{ml}$ cisplatin and/or chloride channel blockers (NPPB; $100 \mu \mathrm{mol} / \mathrm{l})$. MTT solution (10 $\mu \mathrm{l} /$ well; Sigma-Aldrich) was added to the cells, which were then incubated for $4 \mathrm{~h}$ prior to detection. The MTT solution was removed and replaced with DMSO, in order to dissolve the formazan crystals, for 15-30 $\mathrm{min}$. The absorbance was then measured at a wavelength of $570 \mathrm{~nm}$, using a Safire ${ }^{2}$ microplate reader equipped with the Magellan (5.0) reader software (Tecan Group, Ltd, Männedorf, Switzerland).

The rate of apoptosis of the cells was measured by flow cytometry. The cells were cultured for $72 \mathrm{~h},\left(1-2 \times 10^{5}\right.$ cells/sample), then collected and analyzed. Briefly, the cells were washed three times with phosphate-buffered saline (PBS), fixed in chilled $70 \%$ ethanol at $-20^{\circ} \mathrm{C}$ for $30 \mathrm{~min}$, washed a further two times with PBS and incubated with RNase A (50 $\mu \mathrm{g} / \mathrm{ml}$ in PBS) at $37^{\circ} \mathrm{C}$ for $30 \mathrm{~min}$. The cells were then stained with propidium iodide (50 $\mu \mathrm{g} / \mathrm{ml}$; Beyotime, Shanghai, China) for $15 \mathrm{~min}$ and analyzed by flow cytometry (FACS101; BD Biosciences, Franklin Lakes, NJ, USA). The percentage of apoptotic cells was quantified using DNA histograms (FlowJo 7.6.1 software; FlowJo, LLC, Ashland, OR, USA).

Statistical analysis. Data are expressed as the mean \pm standard error. Significant differences were determined by analysis of variance using SPSS version 13.0 software (SPSS Inc., Chicago, IL, USA). $\mathrm{P}<0.05$ was considered to indicate a statistically significant difference.

\section{Results}

Cisplatin-induced apoptosis can be suppressed by chloride channel blockers. To determine the effects of chloride channels on apoptosis, MG-63 cells were cultured with cisplatin $(2 \mu \mathrm{g} / \mathrm{ml})$, either alone, or in combination with chloride channel blockers NPPB (100 $\mu \mathrm{mol} / \mathrm{l})$ and/or tamoxifen $(20 \mu \mathrm{mol} / \mathrm{l})$ for $72 \mathrm{~h}$. The chloride channel blockers significantly suppressed the rate of cisplatin-induced apoptosis, as determined by flow cytometry. The rate of apoptosis inhibition was $84.7 \pm 15.8$ and $94.4 \pm 18.1 \%$, in response to treatment with NPPB and tamoxifen, respectively $(\mathrm{n}=6, \mathrm{P}<0.01$, Fig. 1$)$.

Chloride channel blockers prevent cisplatin-induced suppression of cell proliferation. The results of the present study indicate that chloride channel blockers may protect MG-63 cells against cisplatin-induced apoptosis. Therefore, the present study aimed to determine the effects of chloride channel blockers on the proliferation of cisplatin-treated MG-63 cells. The proliferation of MG-63 cells was evaluated by an MTT assay. The cells were cultured under the following four conditions: Control (DMEM), cisplatin (CDDP), CDDP+NPPB and CDDP+tamoxifen. The cells were cultured for 36 and $72 \mathrm{~h}$, and the optical density of the cells was then 


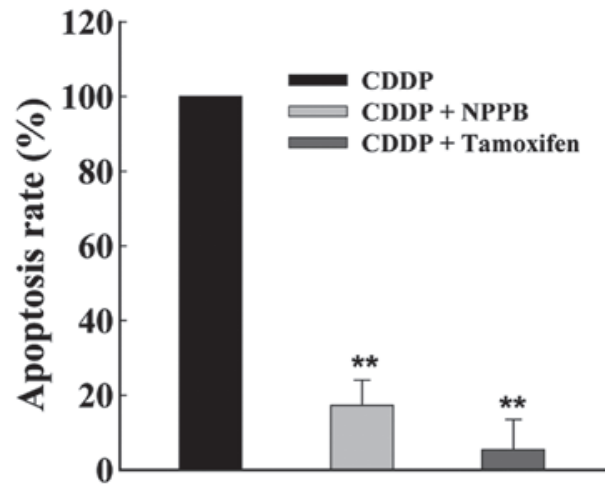

Figure 1. Chloride channel blockers decrease the rate of cisplatin-induced apoptosis in MG-63 human osteosarcoma cells. The cells were treated with cisplatin (CDDP; $2 \mu \mathrm{g} / \mathrm{ml}$ ) in Dulbecco's modified Eagle's medium alone, or in combination with chloride channel blockers 5-nitro-2-(3-phenylpropylamino)-benzoate (NPPB; $100 \mu \mathrm{mol} / \mathrm{l}$ ) or tamoxifen $(20 \mu \mathrm{mol} / \mathrm{l})$ for $72 \mathrm{~h}$. The data represent the mean percentage of inhibition of apoptosis \pm standard error of six experiments. ${ }^{* *} \mathrm{P}<0.01$, vs. the control.

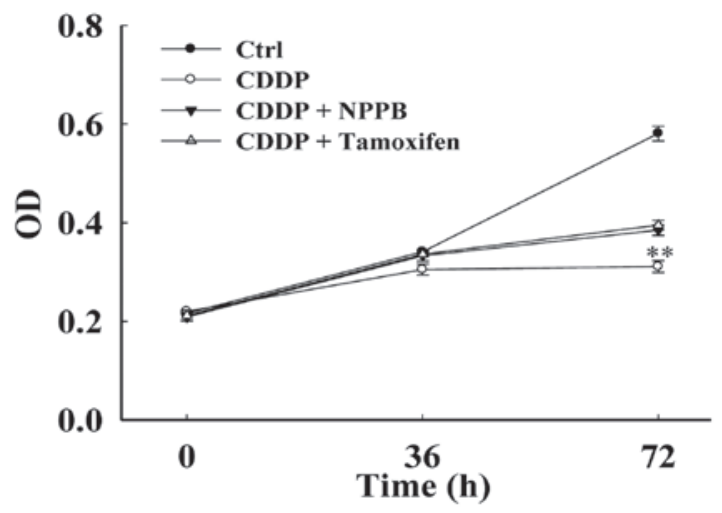

Figure 2. Chloride channel blockers increase proliferation of cisplatin-treated MG-63 human osteosarcoma cells. The cells were cultured in 96-well culture plates (at a density of 2,500 cells/well) in control medium overnight ( 16-18 h), and were then incubated in control medium (Ctrl) or medium containing cisplatin (CDDP; $2 \mu \mathrm{g} / \mathrm{ml})$ alone, or in combination with 5-nitro-2-(3-phenylpropylamino)-benzoate (NPPB; $100 \mu \mathrm{M}$ ) or tamoxifen $(20 \mu \mathrm{M})$ for 36 or $72 \mathrm{~h}$. The relative cell numbers were detected by an MTT assay and the optical density (OD) of the cells was measured. The figure shows the comparison of cell growth to standardized OD values at different time points in MG- 63 cells. The data represent the mean \pm standard error of three experiments. ${ }^{* *} \mathrm{P}<0.01$, vs. the control.

measured using a microplate reader. The inhibition of proliferation was $77.0 \pm 23.5 \%$ following treatment with cisplatin for 72 h (Fig. 2). Treatment with NPPB and tamoxifen suppressed the cisplatin-induced inhibition of proliferation. The inhibition rate was reduced to $30.51 \pm 8.30 \%$ and $45.21 \pm 7.28 \%$, in response to treatment with NPPB and tamoxifen, respectively $(\mathrm{n}=18, \mathrm{P}<0.01)$.

Chloride channel blockers inhibit cisplatin-induced AVD. Live cell imaging was used to detect cell volume. Under isotonic conditions (control), the cell volume was stable (Fig. 3; n=18). However, when the cells were treated with cisplatin, cell volume gradually decreased. Cell shrinkage was detected as early as $10 \mathrm{~min}$ after application of cisplatin. After $6 \mathrm{~h}$, cell volume had decreased by $15.1 \pm 2.2 \% \quad(n=23$, $\mathrm{P}<0.01)$. Cell shrinkage was alleviated in response to treatment
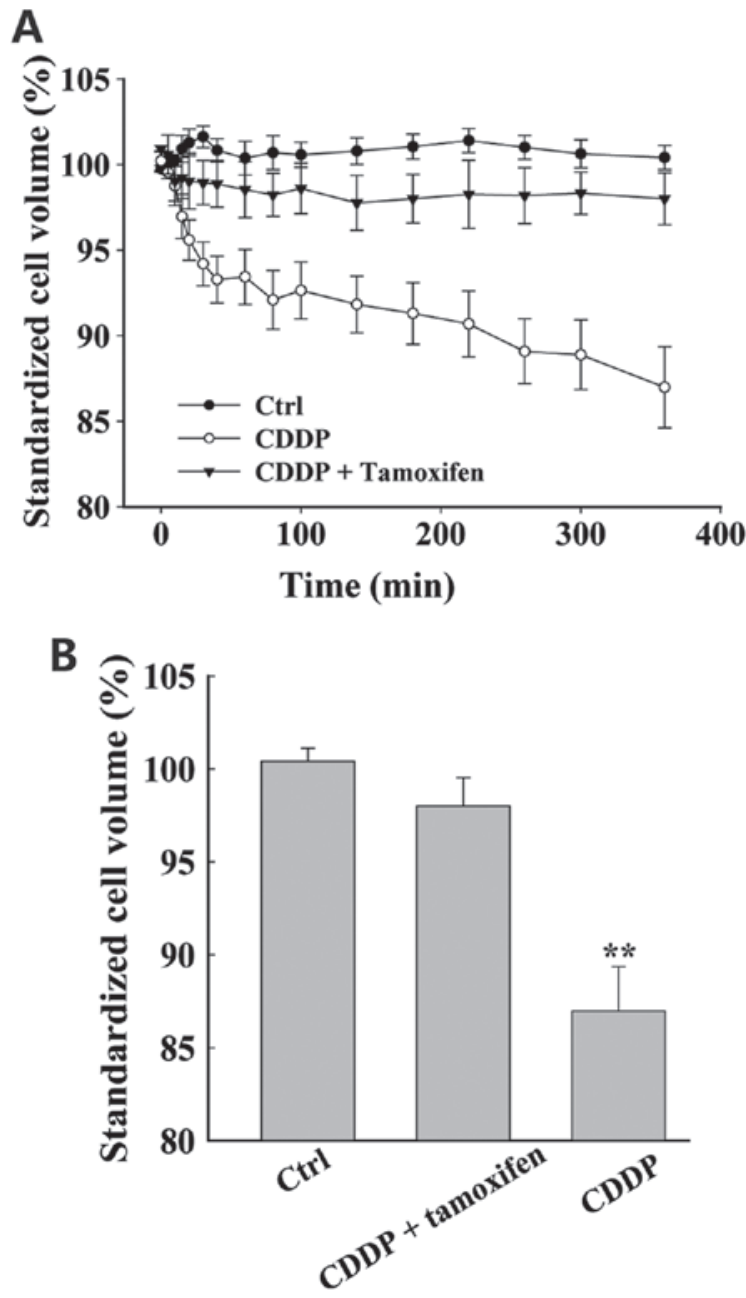

Figure 3. Chloride channel blocker tamoxifen prevents cisplatin-induced decreases in cell volume of MG-63 human osteosarcoma cells. (A) Time-dependent changes in MG-63 cell volume following incubation in isotonic bath solutions, with or without cisplatin (CDDP; $2 \mu \mathrm{g} / \mathrm{ml}$ ) and tamoxifen $(20 \mu \mathrm{M})$ treatment. (B) Final cell volumes following treatment for $360 \mathrm{~min}$ with different bath solutions. Cell volume analysis was standardized to that of the control group. The data represent the mean \pm standard error of 23-32 imaged cells. ${ }^{* *} \mathrm{P}<0.01$, vs. the control.

with chloride channel blockers. Incubation with NPPB (data not shown) and tamoxifen suppressed the cisplatin-induced decrease in cell volume. In addition, the cell volume was not significantly different in the cells treated with chloride channel blockers, as compared with the control cells ( $n=32, P>0.05)$.

Activation of chloride currents by extracellular application of cisplatin. The results of the present study indicate that cisplatin may induce AVD, and it was hypothesized that chloride channels may be involved in this process. Whole cell patch-clamp recordings were taken, in order to determine the effects of cisplatin on chloride channel currents in MG-63 cells. The background chloride current in isotonic solution was weak and stable, with a density of $6.81 \pm 1.02 \mathrm{pA} / \mathrm{pF}$ at $+80 \mathrm{mV}$; and $-5.81 \pm 1.45 \mathrm{pA} / \mathrm{pF}$ at $-80 \mathrm{mV}(\mathrm{n}=15$, Fig. 4). In the majority of cells (7/10 cells), the currents were significantly increased in response to treatment with cisplatin for 10-15 min. The currents reached a plateau with mild outward-rectification at 30-50 min (Fig. 4D). The current 

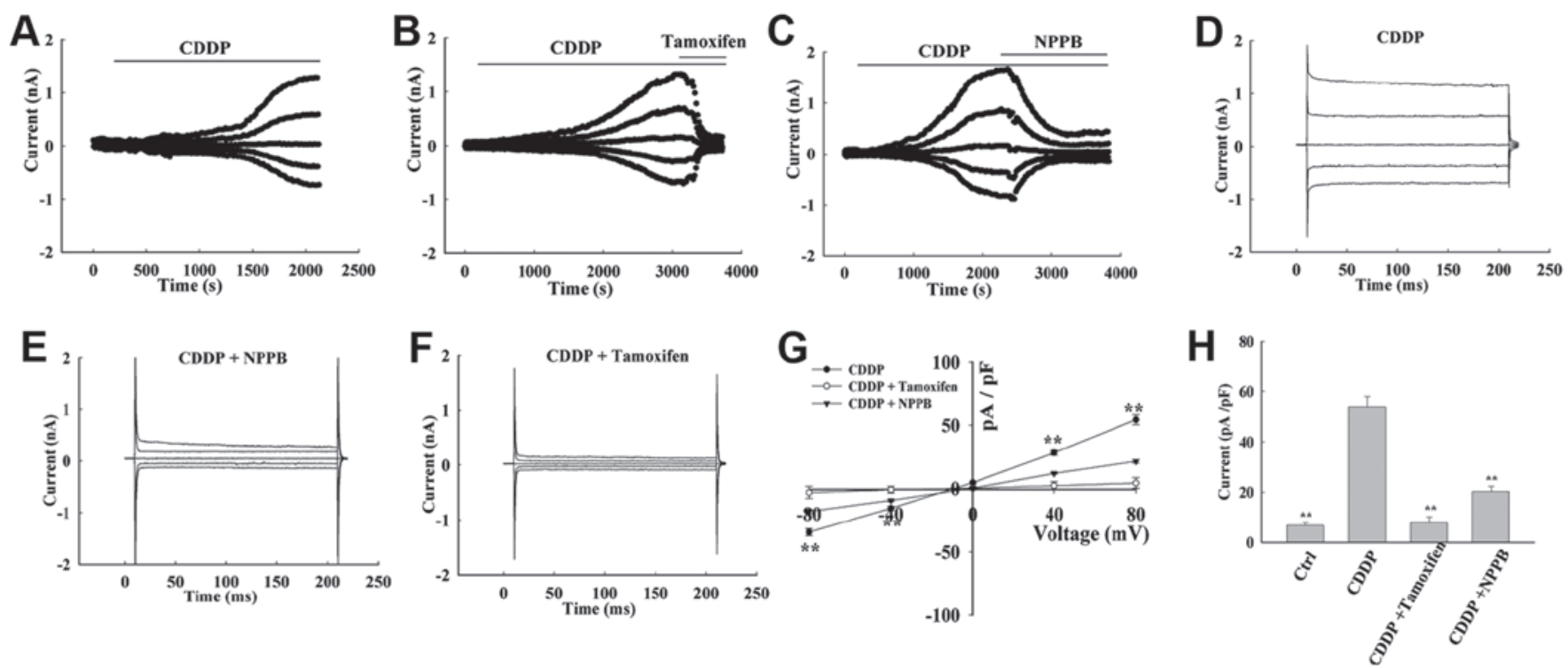

Figure 4. Cisplatin-induced chloride currents are inhibited by chloride channel blockers 5-nitro-2-(3-phenylpropylamino)-benzoate (NPPB) and tamoxifen in MG-63 human osteosarcoma cells. (A) Typical time course of the chloride current activated by cisplatin ( $2 \mu \mathrm{g} / \mathrm{ml})$ in isoosmotic bath solution (CDDP) alone or in combination with chloride channel blockers (B) NPPB $(100 \mu \mathrm{M})$ and $(C)$ tamoxifen $(20 \mu \mathrm{M})$. (D) Typical current traces recorded in the control CDDP bath solutions. Typical timecourse of inhibition of cisplatin-induced chloride currents by the chloride channel blockers (E) NPPB (100 $\mu \mathrm{M})$ and (F) tamoxifen $(20 \mu \mathrm{M})$. (G) Current-voltage relationships recorded in the control isotonic bath solution (Control) and in the cisplatin isoosmotic bath solution (CDDP) (mean \pm standard error, $n=15$ ). (H) Chloride currents of control (Ctrl), cisplatin isoosmotic (CDDP) and cisplatin isoosmotic solutions containing NPPB or tamoxifen (mean \pm standard error of $5-15$ cells; ${ }^{* *} \mathrm{P}<0.01$ vs. CDDP) at $80 \mathrm{mV}$. Cells were initially held at $0 \mathrm{mV}$, and voltage was then stepped to 0 , \pm 40 and $\pm 80 \mathrm{mV}$, repeatedly.

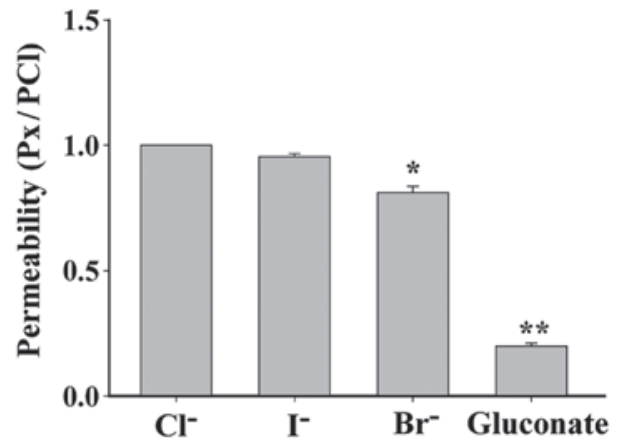

Figure 5. Anion permeability of the cisplatin-activated chloride channel. Anion selectivity of the cisplatin-activated chloride channel was determined by replacing the $70 \mathrm{mM} \mathrm{NaCl}$ of the isotonic solution with equimolar $\mathrm{Na}(\mathrm{X})$, where $\mathrm{X}$ represents the substituted anion $\mathrm{I}^{-}, \mathrm{Br}^{-}$or gluconate. The anion permeability, relative to that of $\mathrm{Cl}^{-}$, was calculated from the shift in reverse potential. The order of anion permeability was $\mathrm{Cl}^{-}=\mathrm{I}>\mathrm{Br}>$ gluconate acid ion. The data represent the mean \pm standard error of six experiments. ${ }^{*} \mathrm{P}<0.05$ and ${ }^{* *} \mathrm{P}<0.01$, vs. $\mathrm{Cl}^{-}$.

displayed an almost linear current-voltage relationship, with an outward current of $53.96 \pm 4.01 \mathrm{pA} / \mathrm{pF}$ at $+80 \mathrm{mV}$, and an inward current of $-41.9 \pm 3.451 \mathrm{pA} / \mathrm{pF}$ at $-80 \mathrm{mV}(\mathrm{n}=12, \mathrm{P}<0.01$, Fig. 4A). There was no time-dependent inactivation observed at \pm 40 and $\pm 80 \mathrm{mV}$. The cisplatin-activated current reversed at $-3.74 \pm 1.43 \mathrm{mV}(\mathrm{n}=15)$, which is close to the calculated $\mathrm{Cl}^{-}$equilibrium potential $(-0.9 \mathrm{mV})$. There was no potassium shown to be present in either the pipette or bath solutions. In addition, equilibrium potentials for $\mathrm{Na}^{+}$and $\mathrm{Ca}^{2+}$ were predicted to be $>+200 \mathrm{mV}$. Therefore, these results support the conclusion that the cisplatin-activated current is generated primarily by $\mathrm{Cl}^{-}$.

Chloride channel blockers inhibit cisplatin-activated chloride currents. Once the cisplatin-activated currents had reached the maximum, the bath solution was changed to cisplatin solution containing NPPB and tamoxifen. Extracellular application of NPPB and tamoxifen inhibited the current (Fig. 4B and C). The outward and inward currents were almost equally inhibited, and the inhibition rate was $70.21 \pm 3.08 \%$ and $97.88 \pm 1.50 \%$ at $+80 \mathrm{mV}$, and $68.321 \pm 4.98 \%$ and $98.36 \pm 2.04 \%$ at $-80 \mathrm{mV}$, respectively ( $\mathrm{n}=5$, Fig. $4 \mathrm{G}$ and $\mathrm{H}$ ). In these experiments, DMSO was used to prepare the NPPB solutions, and the final concentration of DMSO in the bath solutions did not exceed $0.1 \%(\mathrm{v} / \mathrm{v})$. At this concentration, it did not affect cell volume or current, and was not cytotoxic within the $24 \mathrm{~h}$ period of analysis.

Anion selectivity of the cisplatin-activated chloride channel. Anion selectivity of the cisplatin-activated current was determined by replacing $70 \mathrm{mM} \mathrm{NaCl}$ with equimolar $\mathrm{Na}(\mathrm{X})$, where $\mathrm{X}$ represents the substituted anion $\mathrm{I}^{-}, \mathrm{Br}^{-}$, or gluconate. The permeability of $\mathrm{I}^{-}, \mathrm{Br}^{-}$and gluconic acid ion, as compared with $\mathrm{Cl}^{-}$, which was defined as 1 , was: $\mathrm{I}^{-}, 0.95 \pm 0.01(\mathrm{P}>0.05, \mathrm{n}=5)$; $\mathrm{Br}^{-}, 0.81 \pm 0.03(\mathrm{P}<0.05, \mathrm{n}=6)$, gluconic acid ion, $0.20 \pm 0.01$ $(\mathrm{P}<0.01, \mathrm{n}=6)$. Therefore, the order of the anion permeability of the cisplatin-activated channel was $\mathrm{Cl}^{-}=\mathrm{I}>\mathrm{Br}>$ gluconate acid ion (Fig. 5).

\section{Discussion}

Osteosarcoma is the most common primary malignant bone tumor in children and adolescents. There are numerous chemotherapeutic drugs that exert different pharmacological effects; however, the current obstacle to clinical chemotherapy is the development of treatment strategies that kill tumor cells, without harming normal healthy cells (1). Cisplatin is often used as a single agent, or in combination with other drugs, and is effective in the treatment of various types of tumor (13). 
Cisplatin is a platinum complex that exhibits profound cytotoxic effects. It has a strong broad-spectrum anticancer effect, and is the most common drug used to treat nasopharyngeal carcinoma, osteosarcoma and other solid tumors $(14,15)$. Cisplatin can damage DNA and cause apoptosis, and is capable of acting synergistically with various chemotherapeutic drugs to increase effectiveness; however, the mechanisms by which this occurs are not fully understood. Furthermore, cytotoxicity and drug resistance to cisplatin reduce its effectiveness. Understanding how cisplatin exerts its effects is crucial in the development of improved treatment strategies. The present study hypothesized that cisplatin may exert its functions through chloride channels.

Chloride channels are widely distributed throughout mammalian tissues. In addition to regulating cell volume, volume-sensitive chloride channels have been shown to correlate with cell cycle regulation, and proliferation, migration and apoptosis of cells (4,16-22). AVD marks the early stages of apoptosis, and is closely associated with the activation of chloride channels (23). The present study explored the role of chloride channels in cisplatin treatment of osteosarcoma, with the aim of identifying novel targets for osteosarcoma therapy.

The present study examined the role of chloride channels in cisplatin-induced apoptosis of MG-63 cells. Flow cytometry and an MTT assay were used to detect the rate of apoptosis and proliferation, respectively. In the cells treated with cisplatin, cell proliferation was suppressed and the rate of apoptosis was increased. Furthermore, co-treatment of cisplatin with chloride channel blockers NPPB and tamoxifen resulted in a reduction in the rate of cell apoptosis and inhibition of cell proliferation, which had initially been induced by cisplatin. These results suggest that chloride channels are activated and involved in cisplatin-induced apoptosis.

To demonstrate that activation of chloride channels is a key signal controlling the early stages of apoptosis, live cell imaging and whole cell patch-clamp recordings were used to detect cisplatin-induced changes in cell volume and chloride currents, in osteosarcoma cells. Live cell imaging analysis showed that cell volume gradually decreased in response to treatment with cisplatin; this type of continuous cell volume decrease has previously been shown to activate apoptosis $(24,25)$. Whole cell patch-clamp analysis indicated that chloride channel currents were significantly increased upon treatment with cisplatin, and that the cisplatin-activated current was reversed at a potential close to the calculated chloride equilibrium potential $(-0.9 \mathrm{mV})$. The typical current traces indicate that the currents were not time-dependent. In addition, chloride channel blockers were shown to inhibit cisplatin-activated chloride currents. Further experiments were then conducted to determine anion selectivity of the channel, and the order of anion permeability was shown to be $\mathrm{Cl}^{-}=\mathrm{I}^{-}>\mathrm{Br}>$ gluconate acid anion. These results suggest that cisplatin activates chloride channels, opening them and thereby driving the flow of chloride ions out of the cell, causing the cells to shrink, and thus resulting in a decrease in cell volume and ultimately induction of cell apoptosis $(26,27)$.

It is possible that other ion channels may also be involved in osteosarcoma therapy. A previous study showed that capacitative $\mathrm{Ca}^{2+}$ entry influx may activate transient receptor potential channels, which may affect cell proliferation of osteosarcoma cells (28). Kv1.3 is another channel that may be involved in the treatment of osteosarcoma. Previous research demonstrated that a knockdown of Kv1.3 significantly inhibited the growth of MG-63 xenografts (29). In addition, other groups have reported that treatment with trichostatin A can restore functional expression of VSOR chloride channels, and that this may lead to a decrease in the cisplatin resistance of KCP-4 human epidermoid cancer cells. These results suggests that impaired activity of VSOR chloride channels may be involved in the acquisition of cisplatin resistance in this type of cancer (30). Ransom et al (31) demonstrated that glioma cell migration through brain tissue may require volume-activated chloride currents, which participate in cell shape and volume changes. Furthermore, tumor necrosis factor-mediated liver cell death has been shown to be triggered by the activation of $\mathrm{K}^{+}$and $\mathrm{Cl}^{-}$channels, which is an early signal in apoptotic pathways (32). These results further demonstrate that numerous types of ion channels, particularly chloride channels, are involved in tumor growth, apoptosis and migration.

The results of the present study demonstrate that cisplatin activates chloride channels, causing a cell volume decrease, which may lead to apoptosis of osteosarcoma cells $(26,27)$. It may therefore be concluded that chloride channel activation is an early signal in pathways leading to cisplatin-mediated suppression of proliferation and induction of apoptosis in MG-63 cells. Identification of the specific chloride channel activated by cisplatin may be a potential focus of future research.

\section{Acknowledgements}

The present study was supported by the Health Development Research Funds of Peking (grant no. 201302007).

\section{References}

1. Reedijk J: New clues for platinum antitumor chemistry: kinetically controlled metal binding to DNA. Proc Natl Acad Sci USA 100: 3611-3616, 2003.

2. Wang D and Lippard SJ: Cellular processing of platinum anticancer drugs. Nat Rev Drug Discov 4: 307-320, 2005.

3. Woźniak $\mathrm{K}$ and Błasiak J: Recognition and repair of DNA-cisplatin adducts. Acta Biochim Pol 49: 583-596, 2002.

4. Lang F, Busch GL, Ritter M, et al: Functional significance of cell volume regulatory mechanisms. Physiol Rev 78: 247-306, 1998.

5. Shen MR, Droogmans G, Eggermont J, Voets T, Ellory JC and Nilius B: Differential expression of volume-regulated anion channels during cell cycle progression of human cervical cancer cells. J Physiol 529: 385-394, 2000.

6. Zheng YJ, Furukawa T, Tajimi K and Inagaki N: $\mathrm{Cl}^{-}$channel blockers inhibit transition of quiescent $\left(\mathrm{G}_{0}\right)$ fibroblasts into the cell cycle. J Cell Physiol 194: 376-383, 2003.

7. Wang L, Chen L and Jacob TJ: The role of $\mathrm{ClC}-3$ in volume-activated chloride currents and volume regulation in bovine epithelial cells demonstrated by antisense inhibition. J Physiol 524: 63-75, 2000.

8. Shimizu T, Numata $\mathrm{T}$ and Okada $\mathrm{Y}$ : A role of reactive oxygen species in apoptotic activation of volume-sensitive $\mathrm{Cl}^{-}$channel. Proc Natl Acad Sci USA 101: 6770-6773, 2004.

9. Rubera I, Duranton C, Melis N, Cougnon M, Mograbi B and Tauc M: Role of CFTR in oxidative stress and suicidal death of renal cells during cisplatin-induced nephrotoxicity. Cell Death Dis 4: e817, 2013.

10. Min XJ, Li H and Hou SC: Dysfunction of volume-sensitive chloride channels contributes to cisplatin resistance in human lung adenocarcinoma cells. Exp Biol Med (Maywood) 236: 483-491, 2011. 
11. Su J, Xu Y, Zhou L, et al: Suppression of chloride channel 3 expression facilitates sensitivity of human glioma U251 cells to cisplatin through concomitant inhibition of Akt and autophagy. Anat Rec (Hoboken) 296: 595-603, 2013.

12. Yang L, Ye D, Ye W, et al: ClC-3 is a main component of background chloride channels activated under isotonic conditions by autocrine ATP in nasopharyngeal carcinoma cells. J Cell Physiol 226: 2516-2526, 2011.

13. Muggia F: Platinum compounds 30 years after the introduction of cisplatin: implications for the treatment of ovarian cancer. Gynecol Oncol 112: 275-281, 2009.

14. Iizuka N, Hirose K, Noma T, Hazama S, Tangoku A, Hayashi $\mathrm{H}$, et al: The $\mathrm{nm} 23-\mathrm{H} 1$ gene as a predictor of sensitivity to chemotherapeutic agents in oesophageal squamous cell carcinoma. Br J Cancer 81: 469-475, 1999.

15. Quan YH, Kim B, Park JH, Choi Y, Choi YH and Kim HK Highly sensitive and selective anticancer effect by conjugated HA-cisplatin in non-small cell lung cancer overexpressed with CD44. Exp Lung Res 40: 475-84, 2014.

16. Lang F, Föller M, Lang K, et al: Cell volume regulatory ion channels in cell proliferation and cell death. Methods Enzymol 428: 209-225, 2007.

17. Mao J, Li X, Chen W, et al: Cell cycle-dependent subcellular distribution of ClC-3 in HeLa cells. Histochem Cell Biol 137: 763-776, 2012.

18. Mao J, Yuan J, Wang L, et al: Tamoxifen inhibits migration of estrogen receptor-negative hepatocellular carcinoma cells by blocking the swelling-activated chloride current. J Cell Physiol 228: 991-1001, 2013.

19. Okada Y, Sato K and Numata T: Pathophysiology and puzzles of the volume-sensitive outwardly rectifying anion channel. J Physiol 587: 2141-2149, 2009.

20. Zhang H, Zhu L, Zuo W, et al: The ClC-3 chloride channel protein is a downstream target of cyclin D1 in nasopharyngeal carcinoma cells. Int J Biochem Cell Biol 45: 672-683, 2013.

21. Zhu L, Yang H, Zuo W, et al: Differential expression and roles of volume-activated chloride channels in control of growth of normal and cancerous nasopharyngeal epithelial cells. Biochem Pharmacol 83: 324-334, 2012.
22. Zhu L, Zuo W, Yang H, et al: Involvement of volume-activated chloride channels in $\mathrm{H}_{2} \mathrm{O}_{2}$ preconditioning against oxidant-induced injury through modulating cell volume regulation mechanisms and membrane permeability in PC12 cells. Mol Neurobiol 48: 205-216, 2013.

23. Okada Y, Maeno E, Shimizu T, Dezaki K, Wang J and Morishima S: Receptor-mediated control of regulatory volume decrease (RVD) and apoptotic volume decrease (AVD). J Physiol 532: 3-16, 2001.

24. Chen LX, Zhu LY, Jacob TJ and Wang LW: Roles of volume-activated $\mathrm{Cl}^{-}$currents and regulatory volume decrease in the cell cycle and proliferation in nasopharyngeal carcinoma cells. Cell Prolif 40: 253-267, 2007.

25. Okada $\mathrm{Y}$ and Maeno E: Apoptosis, cell volume regulation and volume-regulatory chloride channels. Comp Biochem Physiol A Mol Integr Physiol 130: 377-383, 2001.

26. Wang L,Chen L,Zhu L, et al: Regulatory volume decrease is actively modulated during the cell cycle. J Cell Physiol 193: 110-119, 2002.

27. Okada Y: Cell and volume-sensitive chloride channels: phenotypic properties and molecular identity. Contrib Nephrol 152: 9-24, 2006.

28. Labelle D, Jumarie C and Moreau R: Capacitative calcium entry and proliferation of human osteoblast-like MG-63 cells. Cell Prolif 40: 866-884, 2007.

29. Wu J, Zhong D, Wu X, Sha M, Kang L and Ding Z: Voltage-gated potassium channel Kv1.3 is highly expressed in human osteosarcoma and promotes osteosarcoma growth. Int J Mol Sci 14: 19245-19256, 2013.

30. Lee EL, Shimizu T, Ise T, Numata T, Kohno K and Okada Y: Impaired activity of volume-sensitive $\mathrm{Cl}^{-}$channel is involved in cisplatin resistance of cancer cells. J Cell Physiol 211: 513-521, 2007.

31. Ransom CB, O'Neal JT and Sontheimer H: Volume-activated, chloride currents contribute to the resting conductance and invasive migration of human glioma cells. J Neurosci 21: 7674-7683, 2001

32. Nietsch HH, Roe MW, Fiekers JF, Moore AL and Lidofsky SD: Activation of potassium and chloride channels by tumor necrosis factor alpha. Role in liver cell death. J Biol Chem 275: 20556-20561, 2000. 